\title{
Modulation of peripheral blood derived monocytes/macrophages from leprosy patients using 'tuftsin' for production of reactive oxygen intermediates
}

\author{
S. KHARE*, L. K. BHUTANI $\dagger \&$ D. N. RAO* \\ $*$ Department of Biochemistry \& †Department of Dermatovenereo- \\ logy, All India Institute of Medical Sciences, New Delhi 110029, \\ India
}

Accepted for publication 11 March 1993

\begin{abstract}
Summary Phagocytic cells respond to a variety of membrane stimulants by producing reactive oxygen intermediates (ROI), i.e. $\mathrm{O}_{2}^{-}, \mathrm{H}_{2} \mathrm{O}_{2}$ and $\mathrm{OH} \cdot$ metabolites. Plasma membrane activation is associated with superoxide generating NADPH oxidase, thereby causing the production of these toxic species. Stimulation of phagocytic cells also results in activation of purine catabolism, which directs the metabolic flux through xanthine oxidase to produce the superoxide anion. We previously observed that $\mathrm{BL} / \mathrm{LL}$ macrophages $(\mathrm{M} \phi$ exhibited a premature inability to undergo tuftsin stimulated phagocytosis and microbicidal activity. The present study was undertaken to measure ROI levels in the absence and presence of 'tuftsin' pulsing as a function of in vitro culture age and also correlated these levels with adenosine deaminase (ADA) activity. The latter is known to be a contributor of $\mathrm{O}_{2}^{-}$generation and is also involved in the maturation of the monocyte/macrophage system. The behaviour of normal and tuberculoid monocytes/macrophages were more or less the same, either in the presence or absence of tuftsin, i.e. they showed a progressive increase in ROI production until day 3 , then tapered off in older cultures by day 7 . In contrast, after day 1 , the lepromatous macrophages were unable to undergo tuftsin mediated stimulation for the production of ROI and ADA activity. These findings indicate a defective $\mathrm{M} \phi$ function in lepromatous patients towards tuftsin pulsing, thereby supporting our earlier observations. Thus BL/LL M $\phi$ behaved as if they were aged after 1 day of invitro culture, which may account for an inability to handle Mycobacterium leprae for efficient killing.
\end{abstract}

\section{Introduction}

Mononuclear phagocytes are indispensable to both natural and acquired host immunity. $M$. leprae is an obligate intracellular pathogen that is ingested by and proliferates within

Address for correspondence and reprint requests: Dr D. N. Rao, Associate Professor, Department of Biochemistry, All India Institute of Medical Sciences, New Delhi 110029, India. 
the cells of the monocytes/macrophages. The inability of macrophages in lepromatous leprosy (LL) patients to efficiently kill $M$. leprae is a predominant feature of this form of leprosy and consequently the macrophages in these patients are found to be loaded with M. leprae.

Phagocytic cells respond to a variety of membrane stimulants by the production and extracellular release of reactive oxygen intermediates (ROI), i.e. $\mathrm{O}_{2}^{-}, \mathrm{H}_{2} \mathrm{O}_{2}$ and $\mathrm{OH} \cdot$ metabolites. The production of these potentially active metabolites has been correlated with the intracellular killing of invading pathogens. ${ }^{1,2}$ Recent studies have shown that intracellular pathogen may escape killing mechanisms either by inhibiting the production of ROI or by neutralizing these intermediates. ${ }^{3}$ Phagocytosis or activation of plasma membrane enzymes by stimuli is initiated by the rapid consumption of molecular $\mathrm{O}_{2}$ to form oxygen radicals by the NADPH oxidase system. Furthermore, the purine salvage pathway, xanthine oxidase, has also been implicated as an important contributor of $\mathrm{O}_{2}^{-}$ release by the phagocytic cells. ${ }^{4,5}$ In this pathway adenosine deaminase (ADA) controls the amount of substrate (xanthine) available to xanthine oxidase, which is also required for normal immune function. ${ }^{6}$

In our previous study, the biphasic variation was observed during phagocytosis and the microbicidal response profile of monocytes/macrophages to 'tuftsin' stimulation against Staphylococcus aureus, $M$. tuberculosis and $M$. leprae as a function of culture age, corresponding to that seen with normal, BT/TT and $\mathrm{BL} / \mathrm{LL} \mathrm{M} \phi$ led us to postulate aberrant maturation drives in $\mathrm{BL} / \mathrm{LL}$ cultures (oxidative burst heterogeneity) of monocytes/macrophages. ${ }^{7,8}$ This is further supported by low levels of endogenous serum tuftsin in lepromatous patients. ${ }^{9}$

In view of the aberrant phagocytic and microbicidal functions noticed in BL/LL culture, the present study was undertaken to measure the ROI production as a function of culture age after tuftsin pulsing and to correlate the results, with ADA activity, known to be involved in the maturation profile of monocytes/macrophages.

\section{Materials and methods}

\section{PATIENTS}

A total of 27 normal, $27 \mathrm{BT} / \mathrm{TT}$ and $22 \mathrm{BL} / \mathrm{LL}$ individuals, classified according to their clinical and histopathological findings, were assayed for ROI production and ADA activity. The patients were registered at the leprosy clinic, Department of Dermatovenereology, AIIMS, New Delhi. Patients received anti-Hansen's chemotherapy for less than 6 months in few cases, while most were fresh, untreated cases.

\section{HUMAN MONONUCLEAR CELL VIABILITY AND PURITY}

In brief, peripheral blood mononuclear cells (PBMC) were isolated by density gradient separation on Ficoll-paque. The interphase cells were collected, washed with cold Hank's balanced salt solution (HBSS) and suspended in RPMI-1640 (Gibco-Biocult) medium containing $10 \%$ human $\mathrm{AB}$ serum (heat-inactivated) containing the appropriate antibiotics, at a concentration of $1-2 \times 10^{6} \mathrm{cells} / \mathrm{ml}$. This was then distributed equally into 24-well plates (Linbro, Flow Labs) and incubated for $3 \mathrm{~h}$ at $37^{\circ} \mathrm{C}$ in a moist atmosphere containing $5 \% \mathrm{CO}_{2}$. The non-adherent cells were removed by washing with pre-warmed 
HBSS $\left(37^{\circ} \mathrm{C}\right)$ and the monocyte enriched monolayers were then cultured in RPMI 1640$10 \% \mathrm{AB}$ serum. ${ }^{7}$ The adherent cells were removed at varying time intervals (1-7 days) by cold treatment and scraping with a rubber policeman. Before each assay, the adherent cells from the same individual were pooled, counted and tested for viability by tryphan blue exclusion. Routinely the yield of adherent cells was 10-15\% of PBMC with a viability ranging from 95 to $97 \%$ and non-specific esterase positivity ranging from 90 to $95 \%$. The number of adherent monocytes/macrophage were maintained at $0.4 \times 10^{5}$ cells $/ 100 \mu \mathrm{l} /$ well in 96 well flat bottom plates for all subsequent experiments. All experiments were done twice and each sample was taken in duplicate wells.

\section{SUPEROXIDE ANION ASSAY}

Production of the superoxide anion was based on superoxide dismutase inhibitable reduction of ferric cytochrome $\mathrm{C} .{ }^{10} \mathrm{On}$ the appropriate day of the assay, monocytes/ macrophages were transferred to 96 well plates and were allowed to adhere for $2 \mathrm{~h}$ at $37^{\circ} \mathrm{C}$ in $5 \% \mathrm{CO}_{2} 95 \%$ air. The media was removed and cells were washed with $0.1 \mathrm{ml}$ of prewarmed phenol red free HBSS to ensure uniform monocyte/macrophage monolayers on the bottom of the wells. The monolayers were covered with $80 \mu \mathrm{l}$ of cytochrome $\mathrm{C} \mathrm{(4 \textrm {mg }}$ cytochrome $\mathrm{C} / \mathrm{ml}$ of phenol red free HBSS) and pulsed with tuftsin $(0.22 \mu \mathrm{M}$ and 0.88 $\mu \mathrm{M})$. PMA (32 $\mathrm{nM}$ ) was used as a positive stimulant. A replicate assay was performed in the presence of $20 \mu \mathrm{l}$ of SOD $(0.03 \mathrm{mg} \mathrm{SOD} / \mathrm{ml}$ of HBSS $)$ to verify the contribution of $\mathrm{O}_{2}^{-}$ to the reduction of cytochrome $C$. The reading was taken in an ELISA reader at $550 \mathrm{~nm}$. Since the cells and cytochrome $\mathrm{C}$ solution in the plates were in no way disturbed by the measuring procedure, the plates were allowed to incubate for additional time intervals (30, 60 and $90 \mathrm{~min}$ ) and reread. The amount of $\mathrm{O}_{2}^{-}$produced was calculated from the extinction coefficient for the absorption of reduced cytochrome $\mathrm{C}$, minus oxidized cytochrome $\mathrm{C}$ as read at $550 \mathrm{~nm}$ by the formula $21 \times 10^{3} \mathrm{M}^{-1} \mathrm{~cm}^{-1}$. In the experimental conditions described above, the amounts of $\mathrm{O}_{2}^{-}$produced per well, was expressed as follows:

$$
\text { nanomoles } \mathrm{O}_{2}^{-} \text {per well }=\frac{\text { absorbance at } 550 \mathrm{~nm}}{6 \cdot 3} \times 100 \text {. }
$$

\section{HYDROGEN PEROXIDE ASSAY}

The assay of $\mathrm{H}_{2} \mathrm{O}_{2}$ production was based on HRPO-dependent oxidation of phenol red by $\mathrm{H}_{2} \mathrm{O}_{2}$ into a compound with increased absorbance at $600 \mathrm{~nm} .{ }^{10}$

We added $100 \mu \mathrm{l} /$ well of phenol red solution (PRS) to the cell monolayers. The PRS contained $140 \mathrm{mM} \mathrm{NaCl}, 10 \mathrm{mM}$ potassium phosphate buffer, $\mathrm{pH} 7 \cdot 0,5 \cdot 5 \mathrm{mM}$ dextrose, $0.56 \mathrm{mM}(0.2 \mathrm{~g} / \mathrm{L})$ phenol red and $19 \mathrm{U} / \mathrm{ml}$ of HRPO. Varying concentration of stimulant (tuftsin $0.22 \mu \mathrm{M}$ and $0.88 \mu \mathrm{M}$ ) was added. PMA (32 $\mathrm{nM}$ ) was used as positive control. Another set was kept without any stimulant. The blank was set up by putting an assay (without any cells) containing phenol red solution. The plates were incubated for the desired time period in humidified $5 \% \mathrm{CO}_{2}-95 \%$ air chamber. Reaction was stopped with $10 \mu \mathrm{l}$ of $1 \mathrm{~N} \mathrm{NaOH}$. The reading was taken in an ELISA reader at $600 \mathrm{~nm}$. A standard curve for $\mathrm{H}_{2} \mathrm{O}_{2}$ was established for each plate using $\mathrm{H}_{2} \mathrm{O}_{2}$ ranging from 1 to $40 \mu \mathrm{M}$ concentration with $100 \mu \mathrm{l}$ of PRS and incubating for the desired time period at $37^{\circ} \mathrm{C}$. The 
amounts of $\mathrm{H}_{2} \mathrm{O}_{2}$ liberated by monocyte cultures was calculated through the standard curve.

\section{ADENOSINE DEAMINASE ACTIVITY}

Adenosine deaminase activity was measured essentially by the method of Tritsch et al.," i.e. based on the rate of decrease in absorbance of adenosine at $265 \mathrm{~nm}$.

The monocytes/macrophages monolayer was stimulated with tuftsin $(0 \cdot 22 \mu \mathrm{M}$ and $0 \cdot 88 \mu \mathrm{M})$. Another set of cells was treated with PMA (32 $\mathrm{nM})$ as positive controls. One set of cells was kept without any stimulant. Cells were incubated for 1 hour. After the incubation, cells were lysed by adding $200 \mu \mathrm{l}$ of chilled $0.5 \%$ triton X-100. The cells were scraped gently. The cell lysate was added to another tube containing $40 \mu 11 \mathrm{mM}$ adenosine, $60 \mu \mathrm{l}$ tris buffer, $1.063 \mathrm{M}, \mathrm{pH} \mathrm{7 \cdot 3}$, and $100 \mu \mathrm{l}$ of $\mathrm{H}_{2} \mathrm{O}$, and the decrease in absorbance at $265 \mathrm{~nm}$ was recorded. A change in 1.0 absorbance is considered to be equivalent to $0 \cdot 13 \mu \mathrm{mol}$ of adenosine deaminated. ${ }^{12}$ Results are expressed as nmole ADA activity $/ \mathrm{hr} / 10^{6}$ cells.

\section{STATISTICAL ANALYSIS}

All the experiments were done in duplicate and the results were expressed as the mean \pm SD of the total number of patients in each group. Statistical analysis was done by Student's $t$-test.

\section{Results}

\section{$\mathrm{O}_{2}^{-}$PRODUCTION}

The basal levels of $\mathrm{O}_{2}^{-}$production on day 1 by monocytes of unstimulated cultures of normal and $\mathrm{BL} / \mathrm{LL}$ subjects were within the same range (normal $0.57 \pm 0.45 \mathrm{nmol} / \mathrm{hr} / 10^{6}$ cells, BL/LL $0 \cdot 55 \pm 0 \cdot 41 \mathrm{nmol} / \mathrm{hr} / 10^{6}$ cells) while the basal level was higher in BT/TT M $\phi$, i.e. $1 \cdot 19 \pm 0 \cdot 35 \mathrm{nmol} / \mathrm{hr} / 10^{6}$ cells. When these cultures were stimulated with PMA $(32 \mathrm{nM})$ and tuftsin $(0 \cdot 22 \mu \mathrm{M})$ they showed increased $\mathrm{O}_{2}^{-}$production in normal and BT/TT M $\phi$ as compared to unstimulated monocytes $(p<0 \cdot 01)$, whereas the BL/LL monocytes failed to show the response. However, PMA is able to stimulate $\mathrm{O}_{2}^{-}$production in $\mathrm{BL} / \mathrm{LL}$ monocytes $\left(1.48 \pm 0 \cdot 25 \mathrm{nmol} / \mathrm{hr} / 10^{6}\right.$ cells $)$. At higher concentration of tuftsin $(0.88 \mu \mathrm{M})$, normal and $\mathrm{BT} / \mathrm{TT} \mathrm{M} \phi$ failed to show $\mathrm{O}_{2}^{-}$release and the levels are the same as unstimulated cultures.

The 3-day-old cultures showed a progressive increase in $\mathrm{O}_{2}^{-}$production in normal as well as in BT/TT macrophages upon stimulation, while BL/LL M $\phi$ almost showed the basal levels. In normal individuals, the 3-day-old $\mathrm{M} \phi$ cultures showed a 3-fold increase in $\mathrm{O}_{2}^{-}$production, by any of the stimulants (PMA $32 \mathrm{nM}$ or tuftsin $0.22 \mu \mathrm{M}$ ) (Table 1); 3day-old BT/TT M $\phi$ also showed approximately a 2-fold increase in $\mathrm{O}_{2}^{-}$production by the same stimulants as compared to the unstimulated $\mathrm{M} \phi$ of the same culture age. The basal level of $\mathrm{O}_{2}^{-}$production was higher in $\mathrm{BT} / \mathrm{TT} \mathrm{M} \phi$ as compared to normals (normal $0 \cdot 49 \pm 0 \cdot 22 \mathrm{nmol} / \mathrm{hr} / 10^{6}$ cells, BT/TT $1 \cdot 28 \pm 0 \cdot 45 \mathrm{nmol} / \mathrm{hr} / 10^{6}$ cells).

The 7-day-old $\mathrm{M} \phi$ cultures of all groups under identical conditions behaved very 
Table 1. Day and dose response profile for superoxide anion production by normal and leprosy monocytes/macrophages

\begin{tabular}{|c|c|c|c|}
\hline \multirow[b]{2}{*}{ Unstimulated } & \multirow{2}{*}{$\begin{array}{c}\text { PMA } \\
(32 \mathrm{nM})\end{array}$} & \multicolumn{2}{|c|}{ Tuftsin } \\
\hline & & $(0 \cdot 22 \mu \mathrm{M})$ & $(0.88 \mu \mathrm{M})$ \\
\hline \multicolumn{4}{|l|}{ 1-day-old culture } \\
\hline $\mathrm{N} \quad 0.57 \pm 0.45$ & $1 \cdot 26 \pm 0.72$ & $0.86 \pm 0.87(\mathrm{~A})$ & $0.47 \pm 0.35$ \\
\hline $\mathrm{T} 1 \cdot 19 \pm 0.35$ & $1.98 \pm 0.92$ & $1.47 \pm 0.47$ (B) & $1 \cdot 14 \pm 0 \cdot 84$ \\
\hline L $0.55 \pm 0.41$ & $1.48 \pm 0.25$ & $0.55 \pm 0.18(\mathrm{C})$ & $0 \cdot 45 \pm 0 \cdot 20$ \\
\hline \multicolumn{4}{|l|}{ 3-day-old culture } \\
\hline N $0.49 \pm 0.22$ & $1 \cdot 17 \pm 0 \cdot 89$ & $1 \cdot 33 \pm 0 \cdot 85(\mathrm{D})$ & $1 \cdot 09 \pm 0 \cdot 50$ \\
\hline T $1.28 \pm 0.45$ & $2 \cdot 30 \pm 0 \cdot 60$ & $1.9 \pm 0.80(\mathrm{E})$ & $1.50 \pm 0.59$ \\
\hline L $\quad 0.79 \pm 0.35$ & $0.93 \pm 0.78$ & $0.35 \pm 0.13(\mathrm{~F})$ & $0 \cdot 31 \pm 0 \cdot 16$ \\
\hline \multicolumn{4}{|l|}{ 7-day-old culture } \\
\hline $\mathrm{N} 0.40 \pm 0.27$ & $0.62 \pm 0.48$ & $1.07 \pm 0.59(\mathrm{G})$ & $0.73 \pm 0.26$ \\
\hline T $0.94 \pm 0.30$ & $2 \cdot 13 \pm 0 \cdot 60$ & $1 \cdot 2 \pm 0.48(\mathrm{H})$ & $0.90 \pm 0.59$ \\
\hline L $0.30 \pm 0.047$ & $0.39 \pm 0.09$ & $0 \cdot 20 \pm 0 \cdot 10$ & $0.19 \pm 0.05$ \\
\hline
\end{tabular}

Results expressed ( $\mathrm{nmol} / \mathrm{hr} / 10^{6}$ cells).

$\mathrm{N}=\operatorname{normal}(n=13) ; \mathrm{T}=$ tuberculoid $(n=13)$; L-lepromatous $(n=8)$ values expressed as mean $\pm \mathrm{SD}[n$ as in ( )].

$\mathrm{A}-\mathrm{B}=p<0.01 ; \quad \mathrm{A}-\mathrm{C}=p=\mathrm{NS}^{*}, \quad \mathrm{~B}-\mathrm{C}=p<0.001, \quad \mathrm{E}-\mathrm{F}=p<0.001$, $\mathrm{E}-\mathrm{H}=p<0.05 ; \mathrm{H}-\mathrm{I}=p<0.001$.

$* \mathrm{NS}=$ not significant.

differently. The $\mathrm{O}_{2}^{-}$production tapered off in all groups as the culture aged at any of the concentration of tuftsin.

\section{$\mathrm{H}_{2} \mathrm{O}_{2}$ RELEASE}

The $\mathrm{H}_{2} \mathrm{O}_{2}$ production was also measured in these cultures as a function of culture age (1-7 day). 1-day-old normal monocytes produced a basal level of $17 \cdot 75 \pm 2 \cdot 3 \mathrm{nmol} / \mathrm{hr} / 10^{6} \mathrm{cells}$. When these cells were stimulated with PMA $(32 \mathrm{nM})$, the levels of $\mathrm{H}_{2} \mathrm{O}_{2}$ rose to $476 \cdot 75 \pm 36 \cdot 7 \mathrm{nmol} / \mathrm{hr} / 10^{6}$ cells. Tuftsin $(0 \cdot 22 \mu \mathrm{M})$ stimulation caused a 3 -fold increase in $\mathrm{H}_{2} \mathrm{O}_{2}$ production when compared to basal level of 1-day-old cultures. The basal levels of $\mathrm{BT} / \mathrm{TT}$ and $\mathrm{BL} / \mathrm{LL} \mathrm{M} \phi$ cultures on day 1 were almost the same $\left(8.39 \pm 4.9 \mathrm{nmol} / \mathrm{hr} / 10^{6}\right.$ cells and $7 \cdot 3 \pm 1 \cdot 5 \mathrm{nmol} / \mathrm{hr} / 10^{6}$ cells, respectively). PMA stimulation showed higher $\mathrm{H}_{2} \mathrm{O}_{2}$ release in both the cases, and tuftsin stimulation $(0 \cdot 22 \mu \mathrm{M})$ showed approximately a 5-6fold increase in $\mathrm{H}_{2} \mathrm{O}_{2}$ production. At a higher concentration of tuftsin $(0.88 \mu \mathrm{M})$, normal and BT/TT M $\phi$ of 1-day-old cultures showed an inhibitory effect, whereas the levels of $\mathrm{H}_{2} \mathrm{O}_{2}$ produced by $\mathrm{BL} / \mathrm{LL} \mathrm{M} \phi$ were comparatively less than $0 \cdot 22 \mu \mathrm{M}$ tuf tsin stimulation. On the whole, a 3-fold increase in $\mathrm{H}_{2} \mathrm{O}_{2}$ production was observed when compared to the basal levels.

The 3-day-old cultures of normal and BT/TT behaved in a similar manner in the production of $\mathrm{H}_{2} \mathrm{O}_{2}$ under optimal conditions, whereas BL/LL M $\phi$ behaved differently. The basal production of $\mathrm{H}_{2} \mathrm{O}_{2}$ in normal and BT/TT M $\phi$ was almost the same $(24 \cdot 25 \pm 2 \cdot 8$ $\mathrm{nmol} / \mathrm{hr} / 10^{6}$ cells and $25 \cdot 3 \pm 12 \cdot 0 \mathrm{nmol} / \mathrm{hr} / 10^{6}$ cells, respectively) although there is a slight 
increment when compared to 1-day-old cultures. The BL/LL M $\phi$ showed lower levels of $\mathrm{H}_{2} \mathrm{O}_{2}$ production in unstimulated cultures $\left(5 \cdot 34 \pm 0 \cdot 65 \mathrm{nmol} / \mathrm{hr} / 10^{6}\right.$ cells $)$. PMA stimulation showed a 20 -fold increase in $\mathrm{H}_{2} \mathrm{O}_{2}$ production in all the groups. Tuftsin $(0 \cdot 22 \mu \mathrm{M})$ showed a 3-4-fold increase in $\mathrm{H}_{2} \mathrm{O}_{2}$ production in normal and BT/TT while there was approximately a 6-fold increase in $\mathrm{BL} / \mathrm{LL} \mathrm{M} \phi$ cultures. At higher concentration of tuftsin $(0.88 \mu \mathrm{M})$, the normal and $\mathrm{BT} / \mathrm{TT} \mathrm{M} \phi$ showed basal levels similar to unstimulated cultures, while $\mathrm{BL} / \mathrm{LL} \mathrm{M} \phi$ showed a 4-fold increase compared to the unstimulated cultures.

The 7-day-old cultures showed a decline in $\mathrm{H}_{2} \mathrm{O}_{2}$ production in all 3 groups when compared to 3-day-old cultures of unstimulated $\mathrm{M} \phi$, and although there is a decrease in $\mathrm{H}_{2} \mathrm{O}_{2}$ production in the 7-day-cultures, the fold increase within the same group in 3-dayand 7-day-old cultures are comparable.

\section{ADA ACTIVITY}

In 1 day $\mathrm{M} \phi$ of normal and BT/TT, after pulsing with tuftsin $(0 \cdot 22 \mu \mathrm{M})$, the ADA activity was almost the same (normal $22 \cdot 75 \pm 7 \cdot 02 \mathrm{nmol} / \mathrm{hr} / 10^{6}$ cells; BT/TT $28 \cdot 39 \pm 7 \cdot 2 \mathrm{nmol} / \mathrm{hr} /$ $10^{6}$ cells). The unstimulated cultures of normal and lepromatous types were unable to show detectable ADA activity, while the tuberculoid $\mathbf{M} \phi$ did show this activity $\left(24.37 \pm 1 \cdot 6 \mathrm{nmol} / \mathrm{hr} / 10^{6}\right.$ cells $)$. Surprisingly, the lepromatous cultures showed higher ADA activity $\left(126 \cdot 12 \pm 33.47 \mathrm{nmol} / \mathrm{hr} / 10^{6}\right.$ cells $)$ on stimulation. At a higher concentration of tuf tsin, the BT/TT and BL/LL M $\phi$ showed almost the same ADA activity. In 3day-old normal cultures, tuftsin pulsing showed a 3-fold increase in ADA activity, while tuberculoid $\mathrm{M} \phi$ failed to show a similar response. The BL/LL M $\phi$ also failed to show any detectable ADA activity in stimulated or unstimulated cultures. Higher tuftsin concentration $(0.88 \mu \mathrm{M})$ showed less ADA activity than the unstimulated cultures.

In 7-day-old normal cultures there is a decrease in ADA activity in stimulated cells when compared to 3-day-old cultures. The unstimulated cultures failed to show any detectable ADA activity.

\section{Discussion}

Tuftsin is an endogenous immunomodulator for macrophage phagocytic and microbicidal functions. ${ }^{13}$ One of the most important mechanisms of intracellular killing of ingested micro-organisms or pathogens by mononuclear cells is the generation of toxic oxygen products $^{1,14}$ through NADPH oxidase or xanthine oxidase pathways. The NADPH oxidase is dormant in non-activated phagocytes. It is activated when phagocytes are exposed to the appropriate stimuli and thereby contributes to the microbicidal activity of these cells. Infection leads to increased xanthine oxidase activity, thus also contributing to the release of toxic oxygen radicals. In this study we have compared the release of $\mathrm{O}_{2}^{-}$, $\mathrm{H}_{2} \mathrm{O}_{2}$, and ADA activity in response to tuftsin pulsing on monocytes/macrophages derived from leprosy patients as a function of in vitro culture age. Our results show that $0.22 \mu \mathrm{M}$ tuftsin is the optimal dose for in vitro stimulation, while higher doses of tuftsin $(0 \cdot 88 \mu \mathrm{M})$ show an inhibitory effect. This is in accordance with observations by others. ${ }^{5,15}$

The monocytes/macrophages were pulsed with tuftsin and the time kinetics were 
studied at 30, 60 and 90 min to determine the optimal time for the maximal release of these metabolites. Maximal release was obtained at $60 \mathrm{~min}$ (data not shown). The present study clearly demonstrates that tuftsin augments the release of ROI even in the absence of a phagocytic event. ${ }^{11,16,17,18}$ Moreover, the release of ROI was related to the age of monocyte derived macrophages as well as the clinical spectrum of the disease.

The basal values of $\mathrm{O}_{2}^{-}$released by unstimulated macrophages of tuberculoid individuals was higher than that of lepromatous and healthy subjects. Though in general the 3-day-old macrophage cultures showed maximal levels, the age of the macrophages did not alter the pattern of release. Similarly, tuftsin also showed maximal effects by day 3 on tuberculoid macrophages. In contrast, lepromatous macrophages were not stimulated by tuftsin. Hydrogen peroxide release was also maximal on day 3 for tuberculoid and normal as compared with lepromatous $\mathbf{M} \phi$. At all time points, the latter showed the lowest levels of $\mathrm{H}_{2} \mathrm{O}_{2}$. It was interesting to discover that tuftsin significantly improved $\mathrm{H}_{2} \mathrm{O}_{2}$ release of the hitherto poor lepromatous $\mathrm{M} \phi$. Tuberculoid and normal $\mathrm{M} \phi$ needed a 3-day period to reach maximal levels, while lepromatous $\mathrm{M} \phi$ released maximal levels on day 1. Lepromatous macrophages produced $50 \%$ as much $\mathrm{H}_{2} \mathrm{O}_{2}$ as that of normal macrophages upon stimulation with PMA or tuftsin, supporting the observations of Nathan et al. ${ }^{19}$ Thus this immunomodulator had a differential effect on ROI production as it was ineffective in improving $\mathrm{O}_{2}^{-}$release from the lepromatous $\mathrm{M} \phi$. Interestingly, tuftsin in lower concentrations was a more effective stimulator than at higher concentrations.

Our results show a high level of $\mathrm{H}_{2} \mathrm{O}_{2}$ release by $\mathrm{BL} / \mathrm{LL}$ cultures as compared to $\mathrm{O}_{2}^{-}$; molecular $\mathrm{O}_{2}$ is reduced to $\mathrm{O}_{2}^{-}$within the monocytes/macrophages at a site accessible to SOD, so that $\mathrm{H}_{2} \mathrm{O}_{2}$ is more likely to be secreted than $\mathrm{O}_{2}^{-}$throughout the spectrum. Similar observations or failure to get sufficient $\mathrm{O}_{2}^{-}$release has been noticed by other workers using lepromatous macrophages. ${ }^{20,21,22}$ Mature macrophages are known to be associated with high SOD activity. The high $\mathrm{H}_{2} \mathrm{O}_{2}$ levels with $\mathrm{BL} / \mathrm{LL} \mathrm{M} \phi$ observed in our study further support the view that they appear to be fully differentiated or matured. The level of differentiation and age of in vitro culture can be correlated with the production of reactive oxygen intermediates and biochemical enzymes associated with monocytes/macrophages. Tuprin et $a l .{ }^{23}$ have shown that small monocytes produce increasing amounts of $\mathrm{H}_{2} \mathrm{O}_{2}$ with increasing culture age in vitro. In addition, these cells were stimulatory towards LPS and $\gamma$-IFN. However, large monocytes showed decreased $\mathrm{H}_{2} \mathrm{O}_{2}$ production with increasing age of culture, an observation similar to our findings. It was also observed that peripheral blood PMNs of lepromatous patients were able to reduce Nitroblue tetrazolium ${ }^{24,25}$ with an enhanced endogenous SOD activity. ${ }^{26}$ Further, since M. leprae contained SOD activity, it is probably able to protect itself from the effect of the superoxide radical by converting $\mathrm{O}_{2}^{-}$to the less toxic $\mathrm{H}_{2} \mathrm{O}_{2} \cdot{ }^{27}$ Therefore, when lepromatous leprosy or its like occurs, the multiplication/killing of $M$. leprae within the $\mathrm{M} \phi$ is inhibited by the interaction between $\mathrm{H}_{2} \mathrm{O}_{2}$ and $\mathrm{O}_{2}^{-}$and this is important for the subsequent release of other toxic radicals like $\mathrm{OH} \cdot$ and $\mathrm{O}_{2}^{1}{ }^{3}$ All these results led us to speculate that despite $\mathrm{H}_{2} \mathrm{O}_{2}$ generation in $\mathrm{BL} / \mathrm{LL}$ patients another important metabolite like $\mathrm{O}_{2}^{-}$is also essential to effectively kill $M$. leprae. The unresponsiveness of $\mathrm{M} \phi$ to modulation, and its failure to become sufficiently activated by tuftsin, as seen in present study, especially in $\mathrm{BL} / \mathrm{LL} \mathrm{M} \phi$, could result in growth or multiplication of $M$. leprae inside the macrophages which is one of the characteristic features of lepromatous leprosy. ${ }^{28}$ It also seems that the $\mathrm{T}$ cell activation and specific lymphokine secretion as well 
Table 2. Day and 1-dose response profile of monocytes/macrophages cultured in vitro (1 day-7 day) of normal and leprosy patients for production of hydrogen peroxide

\begin{tabular}{|c|c|c|c|}
\hline \multirow[b]{2}{*}{ Unstimulated } & \multirow{2}{*}{$\begin{array}{c}\text { PMA } \\
(32 \mathrm{nM})\end{array}$} & \multicolumn{2}{|c|}{ Tuftsin } \\
\hline & & $(0 \cdot 22 \mu \mathrm{M})$ & $(0 \cdot 88 \mu \mathrm{M})$ \\
\hline \multicolumn{4}{|l|}{ 1-day-old culture } \\
\hline$N \quad 17 \cdot 75 \pm 2 \cdot 3$ & $476 \cdot 75 \pm 36 \cdot 7$ & $43.08 \pm 13 \cdot 2(\mathrm{~A})$ & $3 \cdot 19 \pm 0 \cdot 14$ \\
\hline T $8.39 \pm 4.9$ & $297 \pm 166$ & $42 \cdot 28 \pm 11 \cdot 3(\mathrm{~B})$ & $2 \cdot 2 \pm 0 \cdot 3$ \\
\hline L $\quad 7 \cdot 3 \pm 1 \cdot 5$ & $228 \pm 51 \cdot 5$ & $44.68 \pm 9.7 \quad$ (C) & $25 \cdot 68 \pm 8 \cdot 6$ \\
\hline \multicolumn{4}{|l|}{ 3-day-old culture } \\
\hline N $24 \cdot 25 \pm 2 \cdot 8$ & $692 \cdot 25 \pm 32$ & $79.96 \pm 8.9 \quad$ (D) & $30 \cdot 3 \pm 4 \cdot 2$ \\
\hline T $\quad 25 \cdot 3 \pm 12$ & $507 \pm 34 \cdot 2$ & $95 \pm 32 \cdot 7$ (E) & $32 \cdot 12 \pm 13 \cdot 5$ \\
\hline L $\quad 5 \cdot 34 \pm 0 \cdot 65$ & $231 \pm 42 \cdot 8$ & $31 \cdot 5 \pm 1 \cdot 62(\mathrm{~F})$ & $21 \cdot 12 \pm 6 \cdot 8$ \\
\hline \multicolumn{4}{|l|}{ 7-day-old culture } \\
\hline $\mathrm{N} \quad 7 \cdot 32 \pm 2$ & $307 \cdot 75 \pm 37$ & $30 \pm 8 \cdot 5 \quad(\mathrm{G})$ & $12 \cdot 79 \pm 5 \cdot 7$ \\
\hline T $\quad 8 \cdot 3 \pm 1 \cdot 6$ & $249 \pm 50$ & $35 \cdot 4 \pm 5 \cdot 4 \quad(\mathrm{H})$ & $20 \cdot 5 \pm 5 \cdot 0$ \\
\hline L $\quad 2 \cdot 8 \pm 1 \cdot 7$ & $155 \pm 11 \cdot 7$ & $19 \cdot 9 \pm 5 \cdot 59$ (I) & $22 \cdot 6 \pm 2 \cdot 3$ \\
\hline
\end{tabular}

Results expressed (nmol/hr/ $/ 10^{6}$ cells).

$\mathrm{N}=$ normal $(n=8) ; \mathrm{T}=$ tuberculoid $(n=8) ;$ L-lepromatous $(n=8)$ values expressed as mean $\pm \mathrm{SD}[n$ as in ( )].
$\mathrm{A}-\mathrm{D}=p<0.001 ; \quad \mathrm{B}-\mathrm{E}=p-<0.001 ;$
$\mathrm{C}-\mathrm{F}=p<0.001 ; \quad \mathrm{D}-\mathrm{G}=p<0.001 ;$

$\mathrm{E}-\mathrm{H}=0<0.001 ; \mathrm{F}-\mathrm{I}=p<0.05$.

as the unresponsiveness of macrophages for activation could also be linked to aberrant $\mathrm{M} \phi$ function in LL patients.

Fischer et al. ${ }^{6}$ have shown the importance of ADA for normal macrophage function and for the maturation of monocytes to macrophages. A hereditary deficiency of ADA has been shown to be associated with defective cellular and humoral immunity. ${ }^{29}$

In our study, except in 1-day BL/LL macrophage, measurable ADA activity was not detected in 3-day- and 7-day-old cultures. Since no measurable ADA activity was seen after $60 \mathrm{~min}$ of tuftsin pulsing, a parallel 15-min experiment was conducted with tuftsin pulsing to discover if ADA activity was detectable any earlier, but measurable ADA activity was not detected in these cultures. Interestingly, we found a direct relationship between ADA activity and $\mathrm{O}_{2}^{-}$generation in normal and BT/TT groups.

Our findings show that fresh monocytes (1 day old) from either end of the spectrum of leprosy have basal production of metabolites, and after pulsing with an optimal dose of tuftsin the levels of these metabolites increase progressively. This increase was statistically significant $(p<0 \cdot 01)$ (Tables 1-3). The basal level of ROI production is consistent with our earlier findings that the rate of microbicidal activity by $\mathrm{M} \phi$ from all 3 groups did not appear to be impaired. ${ }^{8}$ The 3-day-old cultures of normal and BT/TT M $\phi$ behaved similarly in the absence of any stimulant, but on stimulation showed a progressive rise in ROI production, a finding similar to that seen with human monocytes when they differentiate to macrophages in vitro. ${ }^{27}$ The macrophages of BL/LL patients behaved as if they had prematurely aged and differentiated. In all 3 groups, the 7-day-old cultures failed to generate ROI production. 
Table 3. Day and dose response of monocytes/macrophages derived from peripheral blood of normal and leprosy patients for adenosine deaminase activity

\begin{tabular}{|c|c|c|c|}
\hline \multirow[b]{2}{*}{ Unstimulated } & \multirow{2}{*}{$\begin{array}{c}\text { PMA } \\
(32 \mathrm{nM})\end{array}$} & \multicolumn{2}{|c|}{ Tuftsin } \\
\hline & & $(0 \cdot 22 \mu \mathrm{M})$ & $(0 \cdot 88 \mu \mathrm{M})$ \\
\hline \multicolumn{4}{|l|}{ 1-day-old culture } \\
\hline $\mathrm{N} \quad \mathrm{ND}$ & $44 \cdot 12 \pm 5 \cdot 32$ & $22 \cdot 75 \pm 7 \cdot 02$ (A) & $14.0 \pm 11.9$ \\
\hline T $24.37 \pm 1 \cdot 6$ & $19.65 \pm 10.88$ & $28.39 \pm 7.2$ & $38.17 \pm 4.07$ \\
\hline $\mathrm{L} \quad \mathrm{ND}^{-}$ & ND & $126 \cdot 12 \pm 33 \cdot 47$ & $37.91 \pm 22.5$ \\
\hline \multicolumn{4}{|l|}{ 3-day-old culture } \\
\hline N $31 \cdot 17 \pm 1.05$ & $54 \cdot 00 \pm 26 \cdot 2$ & $93 \cdot 16 \pm 31 \cdot 9$ (B) & $22 \cdot 7 \pm 6 \cdot 4$ \\
\hline $\mathrm{T} \quad 30.9 \pm 6.7$ & $37 \cdot 3 \pm 7 \cdot 9$ & $25 \cdot 4 \pm 9 \cdot 2$ & $15 \cdot 5 \pm 6 \cdot 5$ \\
\hline $\mathrm{L} \quad \mathrm{ND}$ & $\mathrm{ND}$ & $\mathrm{ND}$ & ND \\
\hline \multicolumn{4}{|l|}{ 7-day-old culture } \\
\hline ND & $43 \cdot 36 \pm 22 \cdot 0$ & $49 \cdot 40 \pm 5 \cdot 5 \quad$ (C) & $15 \cdot 75 \pm 6 \cdot 2$ \\
\hline T ND & ND & ND & ND \\
\hline L ND & ND & ND & ND \\
\hline
\end{tabular}

Results expressed ( $\mathrm{nmol} / \mathrm{hr} / 10^{6}$ cells).

$\mathrm{N}=$ normal $(n=6) ; \mathrm{T}=$ tuberculoid $(n=6)$; L-lepromatous $(n=6)$.

$\mathrm{ND}=$ not detectable.

Values expressed as mean $\pm \mathrm{SD}[n$ as in ( )].

$\mathrm{A}-\mathrm{B}=p<0.001 ; \mathrm{B}-\mathrm{C}=p<0.01$.

The possible cause of decreased ROI production seen with older cultures could be due to several possibilities. These are (a) an increased activity of $\mathrm{H}_{2} \mathrm{O}_{2}$ scavengers af ter day 3 of culture, ${ }^{27}$ (b) specific enzyme/enzymes defects associated with ROI production; and (c) the functional heterogeneity of monocytes/macrophages as suggested by Norris et al. ${ }^{30}$ Therefore, the differentiation of monocytes to macrophages in vitro involves a gradual transition of morphologic, physiologic, and biochemical changes, and the survival of a given pathogen inside it may depend on the level of differentiation of the monocyte that it infects.

This is the first reported study measuring ROI intermediates and ADA activity from the monocytes/macrophages of leprosy patients after tuftsin pulsing as a function of the age of culture. It is tempting to speculate that in addition to the protective mechanisms of the pathogen, biochemical factors are also involved in the defective macrophage function of lepromatous patients. We are currently measuring the levels of different second messengers like $\left[\mathrm{Ca}^{++}\right]_{i}$, cyclic nucleotides and tuftsin receptor sites/affinities on the monocytes/macrophages derived from the leprosy individuals in the presence and absence of tuftsin stimulation.

\section{Acknowledgements}

We are grateful to CSIR, New Delhi, India for financial assistance and fellowship to one of us (SK). We wish to give special thanks to Dr I. Nath for critical comments, suggestions and for reviewing the manuscript. 


\section{References}

1 Babior BM. Oxygen-dependent microbial killing by phagocytes. $N$ Engl J Med, 1978; 298: 659-68.

2 Nathan CF, Nogueria N, Juangbhrich C, Ellis J, Cohn ZA. Activation of macrophages invivo and in vitro. Correlation between hydrogen peroxide release and killing of Trypanosoma cruzi. J exp Med, 1979; 149: 1056-68.

${ }^{3}$ Murray HW, Cohn ZA. Macrophage oxygen-dependent antimicrobial activity. I. Susceptibility of Toxoplasma gondii to oxygen intermediates. J exp Med, 1979; 150: 938-9.

${ }^{4}$ Chan TS. Purine excretion by mouse peritoneal macrophages lacking adenosine deaminase activity. Proc Natl Acad Sci USA, 1979; 76: 925-9.

5 Tritsch GL, Niswander PW. Purine salvage pathway enzyme activity in Tuftsin stimulated macrophages. Ann NY Acad Sci, 1983; 419: 87-92.

6 Fischer D, Weyden MBV, Snyderman R, Kelley WN. A role for adenosine deaminase in human monocytes maturation. J Clin Invest, 1976; 58: 399-407.

7 Iyer RR, Prasad HK, Bhutani LK, Rao DN. Modulation of human lepromatous monocytes-macrophages functions in vitro by tuftsin. Int J Immunopharmac, 1990; 12: 847-58.

8 Iyer RR, Prasad HK, Bhutani LK, Rao DN. Effect of tuftsin stimulation on the microbicidal activity exerted by blood monocytes-macrophages of leprosy patients. Int J Immunopharmac, 1990; 12: 859-69.

9 Kaur J, Khare S, Bhutani LK, Rao DN. Enzyme immunoassay of phagocytosis stimulating tetrapeptide 'Tuftsin' in normal and leprosy sera. Int J Le pr, 1991; 59: 576-81.

10 Pick E, Mizel D. Rapid microassays for the measurement of superoxide and hydrogen peroxide production by macrophages in cultures using an automatic enzyme immunoassay reader. J Immunol Methods, 1981; 46: 211-26.

11 Tritsch GL, Niswander PW. Adenosine deaminase activity and superoxide formation during phagocytosis and membrane perturbation of macrophages. Immunol Commun, 1981; 10: 1-8.

12 Tritsch GL. Adenosine aminohydrolase inhibition in cosolvent buffer mixtures. Arch Biochem Biophys, 1974; 161: 698-74.

13 Najjar VA. Tuftsin, a natural activator of phagocytic cells: an overview. Ann NY Acad Sci, 1983; 419: 1-11.

14 Johnston RB, Godzik Jr. GA, Cohn ZA. Increased superoxide anion production by immunologically activated and chemically elicited macrophages. J Exp Med, 1978; 148: 115-27.

15 Tzehoval E, Segal S, Stabinsky Y, Fridkin M, Spirer Z, Feldmna M. Tuf tsin (an Ig. associated tetrapeptide) triggers the immunogenic function of macrophages: general implications to activation of programmed cell. Proc Natl Acad Sci USA, 1978; 75: 3400-4.

16 Hartung HP, Toyka KV. Tuftsin stimulates the release of oxygen radicals and thromboxane from macrophages. Immunol Lett, 1983; 6: 1-6.

17 Hartung HP, Toyka KV. Augmentation of oxidative and arachidonate metabolism in macrophages by tuftsin (Thr-Lys-Pro-Arg). Agents Actions, 1984; 15: 38.

18 Kain Z, Alkan M, Ghaimovitz G, Segal S, Fridkin M, Levy R. Human peritoneal macrophage activity is increased by tuftsin. Immunol Lett, 1989; 21: 257-61.

19 Nathan CF, Kaplan G, Levis WR, Nusrat A, Witmer MD, Sherwin SA, Job CK, Horowitz CR, Steinman RM, Cohn ZA. Local and systemic effects of intradermal recombinant interferon-Y in patients with lepromatous leprosy. $N$ Engl J Med, 1986; 315: 6-15.

20 Holzer TJ, Nelson KE, Schauf E, Crispen RG, Andersen BR. Mycobacterium leprae fails to stimulate phagocytic cell superoxide anion generation. Infect Immun, 1986; 51: 514-26.

21 Marolia J, Mahadevan PR. Superoxide production from macrophages of leprosy patients af ter stimulation with Mycobacterium leprae. J Biosci, 1987; 12: 273-9.

22 Marolia J, Mahadevan PR. Mycobacterium leprae mediated stimulation of macrophages from leprosy patients and hydrogen peroxide production. J Biosci, 1988; 13: 295-303.

23 Tuprin J, Hersch HE, Lopez-Berestein. Characterization of small and large human peripheral blood monocytes: effects of in vitro maturation of hydrogen peroxide release and on the response of macrophage activation. J Immunol, 1986; 136: (II) 4194-8.

24 Goihman-Yahr MG, Rodriguez-Ochoa, Aranzaz UN, Inardi ME, Gomez de Ocanto A, Convit J. In vitro activation of neutrophils by suspensions of Mycobacterium leprae. Int J Lepr, 1970; 47: 570-4.

25 Lim SD, Kim WS, Kim GS, Good RA, Park BH. NBT responses of neutrophils and monocytes in leprosy. Int J Lepr, 1974; 42: 150-3.

26 Niwa Y, Sakane T, Miyachi Y, Ozaki M. Oxygen metabolism in phagocytes of leprotic patients: enhanced endogeneous superoxide dismutase activity and hydroxyl radical generation by clofazamine. $J$ Clin Microbiol, 1984; 20: 837-42.

27 Nakagawara A, Nathan CF, Cohn ZA. Hydrogen peroxide metabolism in human monocytes during differentiation in vitro. J Clin Invest, 1981; 68: 1243-52.

28 Samuel DR, Godal T, Myrvang B, Song YK. Behaviour of Mycobacterium leprae in human macrophages in vitro. Infect Immun, 1973; 8: 446-9. 
29 Giblett ER, Anderson JE, Cohen F, Pollera B, Meuwissen HJ. Adenosine-deaminase deficiency in two patients with severely impaired cellular immunity. Lancet, 1972; 2: 1067-9.

${ }^{30}$ Norris DA, Morris RM, Sanderson RJ, Kohler RF. Isolation of functional subsets of human peripheral blood monocytes. J Immunol, 1979; 123: 166-72.

Lepr Rev (1993) 64, 208-218

\title{
Modulation des monocytes/macrophages dérivés du sang périphérique de malades lépreux en utilisant 'Tuftsin' pour produire des intermédiaires de l'oxygène activé
}

\author{
S. Khare, L. K. Bhutani et D. N. RaO
}

Résumé Les cellules de phagocytes répondent à divers stimulants de la membrane en produisant des intermédiaires de l'oxygène activé (ROI), c'est-à-dire les métabolites $\mathrm{O}_{2}^{-}, \mathrm{H}_{2} \mathrm{O}_{2}$ et $\mathrm{OH} \cdot$. L'activation de la membrane plasmatique est associée à l'opxydase NADPH génératrice de superoxyde, ce qui provoque la production de ces substances toxiques. La stimulation des phagocytes aboutit également à l'activation du catabolisme de la purine, qui dirige le métabolisme, par la voie xanthine-oxydase, vers la production de l'anion superoxyde. Nous avions observé auparavant que les macrophages BL/LL (Mø) perdaient prématurément leur faculté de subir la phagocytose et l'activité microbicide stimulées par la tuftsine. L'objet de cette étude était de mesurer les taux de ROI avec ou sans flux de 'tuftsine' en fonction de l'âge de la culture in vitro et aussi de rapporter ces taux à l'activité adénosine-déaminase (ADA). On sait que cette dernière contribue à la production $\mathrm{de}_{2}^{-}$etr joue un rôle dans la maturation du système monocyte/macrophage. Le comportement des monocytes/ macrophages mormaux et tuberculoïdes était similaire en présence ou en l'absence de tuftsine, c'est-à-dire qu'il présentait un accroissement progressif de la producton de ROI jusqu'au jour 3 de culture, puis un ralentissement sur les cultures plus vieilles, au jour 7. Par contre, après le jour 1, les macrophages lépromateux n'étaient pas capables d'être induits par la tuftsine à produire ROI et à activer ADA. Ces résultats mettent en évidence une déficience de la fonction Mø chez les patients lépromateux envers le flux tuftsine, ce qui confirme nos observations précédentes. Ainsi les macrophages BL/LL se comportent comme s'ils étaient déja vieillis après un jour de culture in vitro, ce qui expliquerait leur impuissance à éradiquer efficacemnt Mycobacterium leprae.

\section{Modulación de los monocitos/macrófagos de la sangre periférica de pacientes leprosos, usando 'Tuftsin' para la producción de productos intermedios de oxígeno reactivo}

\author{
S. Khare, L. K. Bhutani y D. N. RaO
}

Resumen Les céculas fagocítas responden a muchos diferentes estimulantes de membrana mediante la producción de productos intermedios de oxígeno reactivo (ROI), por ejemplo, los metabolitos $\mathrm{O}_{2}^{-}, \mathrm{H}_{2} \mathrm{O}_{2}$ y $\mathrm{OH}^{\cdot}$. La activación de la membrana plásmica está asociada con oxidasa NADPH que genera superóxido, causando de este modo la producción de estas especies tóxicas. La estimulación de células fagocíticas también resulta en la activación del catabolismo purínico que dirige el flu jo metabólico a través de la oxidasa xantínica para producir el anión de superóxido. Hemos observado con anterioridad que los micróf agos BL/LL exhiben una inhabilidad prematura de fagocitosis estimulado por el 'Tuftsin', y de actividad microbicida. El estudio actual fue realizado para medir los niveles de ROI en la ausencia y presencia de pulsación de 'Tuftsin', en función de la edad del cultivo en vitro, y también correlacionar estos niveles con la actividad de deaminasa adenosínica (ADA). Se sabe que éste es un contribuidor a la generación de $\mathrm{O}_{2}^{-}$, y también está implicada en la maduración del sistema monocito/macrófago. El comportamiento de monocitos/macrófagos normales y tuberculoides es más o menos idéntico, sea en la presencia o ausencia de 'Tuftsin', es decir, hubo un aumento progresivo de la producción de ROI hasta el día número 3, luego hubo una disminución gradual en los cultivos más viejos. Vuelta en cambio, después del día 1, no se podían estimular los macrófagos lepromatosos mediante 'Tuftsin' para que tengan actividad ROI y ADA. Estos resultados indican una función $\mathbf{M} \phi$ defectuosa a la pulsación de 'Tuftsin' por parte de los pacientes lepromatosos, confirmando nuestras observaciones anteriores. Así, el M $\phi$ BL/LL se comportó como si se hubiera enve jecido después de un día en un cultivo en vitro, lo cual puede explicar su letalidad ineficaz frente a Mycobacterium leprae. 